\title{
Variation of market power across different food supply chains
}

\author{
Mykola Dereva ${ }^{1, *}$, and Miroslava Rajčániová ${ }^{1,2}$ \\ ${ }^{1}$ Slovak University of Agriculture in Nitra, Faculty of Economics and Management - Department of \\ Economic Policy. Tr. A. Hlinku 2, 94976 Nitra, Slovakia \\ ${ }^{2}$ The University of West Bohemia, Faculty of Economics - Department of Economics and Quantitative \\ Methods. Univerzitni 22, 30614 Pilsen, Czech Republic
}

\begin{abstract}
.
Research background: The analysis of the competitiveness between producers, processors and retailers in food supply chains has always been drawing a high level of attention. It has become even more topical issue for researchers and policymakers after the global food crisis in 2008.

Purpose of the article: The goal of this paper is to analyse empirical studies of market power and to investigate if some supply chains are systematically more prone to excessive market power than others.

Methods: For this study, we have collected a wide range of recent studies investigating the processors' market power index in the food supply chains. In total, in our analysis, we used 472 unique market power index estimates and employed various linear regression models to investigate their determinants.

Findings \& Value added: Our findings suggest that, on average, the reported degree of market power in the USA is almost twice as high as in other countries. At the same time, market power estimates related to the meat, dairy and horticulture industries are systematically higher than the ones related to other supply chains. Finally, we observed that, on average, supply chains related to highly perishable products tend to have lower market power estimates associated with them, than other supply chains. Our results have important implications for future investigation of the structural source of market power and unfair trade practices.
\end{abstract}

Keywords: Market Power; Food Supply Chains; Bargaining Power.

JEL Classification: D43; L13; L16; L66.

\footnotetext{
*Corresponding author: derevanikolay@gmail.com
} 


\section{Introduction}

Analysis of the market power (MP) along food supply chains have a long history in economic literature and it was becoming even more discussable during the last few decades due to the specific development of producer and consumer prices. While both consumer and producer food prices had increased rapidly during the global food crisis in 2007-2008, producer prices quickly dropped below the pre-2007 level in 2009, consumer prices, however, remained high [47]. Consequently, the European Commission warned of adverse long-term effects of the oligopsony power of processors and retailers for the entire agri-food sector [15].

Even though that there were plenty approaches developed, the range of methods used empirically can be summarised to three main methods: Production-Theoretic Approach (PTA), General Identification Method (GIM) and Stochastic Frontier Estimation (SFE) framework. Each of these approaches has its strengths and weaknesses; describing this is beyond the scope of this paper.

Most of these modern empirical approaches are mainly focused on deriving and measuring of the level of market power. Their main drawback is that even though an estimate for the market power is obtained, the source of the market power is not identified, which limits the explanatory power of these models.

Therefore, even though that market power has long been highly topical subject, the empirical research determining the level of MP remains to be scarce. While the early studies, using structure conduct performance, tried to bring insights on the causes of market power, the reliability of their estimates was heavily criticised. On the other hand, the modern approaches, provide more reliable market power estimates, but their ability to explain the causes of market power is limited.

In this paper, we decided to investigate trends and patterns of Market Power throughout various supply chains, countries and time periods, using the metanalysis approach. Our study has three main objectives: (1) provide an overview of the recent empirical MP studies related to agriculture and food supply chains, (2) investigate the underlying industry-specific determinants related to MP estimates.

This paper is organised as follows: first, we describe data collected as well as dependent and independent variables that are used in our analysis, then we discuss the results and the last chapter brings the conclusions.

\section{Data and Methods}

Our data is based on the level of processors' market power estimates collected from 52 recently published papers. To the best of our knowledge, we collected the most comprehensive list of studies investigating processors' MP in the agri-food supply chains compiled in recent years. All of the studies focus on the estimation of a Market Power Index (MPI) related to a specific approach, sector, the direction of MP, product etc. In total, in our analysis, we use 472 unique MPI estimates (Table 1).

We employed four linear models estimated via OLS and one robust linear model to analyse the level of MP estimates between most dominate estimation approaches and the determinants of MP estimates.

\section{Dependent variable}

Our dependent variable is a Market Power Index that can be described in the following way: when the market is competitive, the product price equals marginal costs (MC), so the mark-up component is zero. However, in a situation with market power, the literature has focused on the identification of monopoly pricing from the evidence that output price (P) exceeds the marginal cost. Traditionally MC is calculated from an estimated cost function. 
Mark-up is then derived from (P - MC) /MC, a positive value of mark-up indicates the presence of non-competitive behaviour in the market. The higher the mark-up is, the greater is the degree of market power or, in other words, the market is closer to monopoly [21]. We use log-transformed MPIs as a dependent variable in throughout our analysis. Log transformation was done to alleviate heteroscedasticity issues and to ameliorate the interpretation of the results.

Table 1. List of Studies Used

\begin{tabular}{|c|c|c|c|c|c|}
\hline Authors & Approach & $\begin{array}{c}\text { Type of } \\
\text { Marker Power }\end{array}$ & $\begin{array}{c}\text { Data } \\
\text { Frequency }\end{array}$ & $\begin{array}{l}\text { Observation } \\
\text { Period }\end{array}$ & $\begin{array}{c}\text { Number of } \\
\text { MPIs }\end{array}$ \\
\hline (Ahn and Lee, 2010) & GIM & Oligopoly & Yearly & $1975-2002$ & 1 \\
\hline (Anders, 2008) & GIM & Oligopsony & Monthly & $1995-2000$ & 2 \\
\hline (Anders, 2008) & GIM & Oligopoly & Monthly & $1995-2000$ & 2 \\
\hline (Appelbaum, 1982) & PTA & Oligopoly & Yearly & $1947-1971$ & 2 \\
\hline (Azzam and Pagoulatos, 1990) & PTA & Oligopsony & Yearly & $1959-1982$ & 1 \\
\hline (Azzam and Pagoulatos, 1990) & PTA & Oligopoly & Yearly & 1959-1982 & 1 \\
\hline (Bakucs et al., 2009) & PTA & Oligopsony & Monthly & $1993-2003$ & 1 \\
\hline (Bakucs et al., 2009) & PTA & Oligopsony & Monthly & $1995-2004$ & 1 \\
\hline (Bergman and Brannlund, 1995) & PTA & Oligopsony & Yearly & $1960-1988$ & 1 \\
\hline $\begin{array}{l}\text { (Bettendorf and Verboven, } \\
\text { 2000) }\end{array}$ & GIM & Oligopoly & Monthly & 1992-1996 & 1 \\
\hline (Bhuyan and Lopez, 1997) & PTA & Oligopoly & Yearly & $1972-1987$ & 3 \\
\hline (Bhuyan and Lopez, 1998) & PTA & Oligopoly & Yearly & $1972-1987$ & 38 \\
\hline $\begin{array}{l}\text { (Čechura, Kroupová and } \\
\text { Hockmann, 2015) }\end{array}$ & SFE & Oligopoly & Yearly & 2003-2012 & 25 \\
\hline (Chen and Yu, 2018) & GIM & Oligopsony & Monthly & $2008-2016$ & 1 \\
\hline $\begin{array}{l}\text { (Chidmi, Lopez and Cotterill, } \\
\text { 2005) }\end{array}$ & GIM & Oligopoly & Monthly & $1996-2000$ & 1 \\
\hline (Chirinko and Fazzari, 1994) & PTA & Oligopoly & Yearly & 1973-1986 & 1 \\
\hline (Chirinko and Fazzari, 1994) & PTA & Oligopoly & Yearly & $1973-1987$ & 1 \\
\hline (Mello and Brandao, 1999) & PTA & Oligopoly & Yearly & $1962-1991$ & 1 \\
\hline (Genesove and Mullin, 1998) & GIM & Oligopoly & Yearly & $1890-1914$ & 1 \\
\hline (Hockmann and Vöneki, 2009) & PTA & Oligopsony & Monthly & $1998-2006$ & 1 \\
\hline $\begin{array}{l}\text { (Hovhannisyan and Gould, } \\
\text { 2012) }\end{array}$ & GIM & Oligopoly & Weekly & 2001-2006 & 1 \\
\hline (Ji and Chung, 2016) & PTA & Oligopsony & Monthly & $1980-2009$ & 1 \\
\hline $\begin{array}{l}\text { (Kumbhakar, Baardsen and } \\
\text { Lien, 2012) }\end{array}$ & SFE & Oligopoly & Yearly & $1974-1991$ & 2 \\
\hline (Lopez, 1984) & PTA & Oligopoly & Yearly & $1965-1979$ & 1 \\
\hline (Lopez and You, 1993) & GIM & Oligopsony & Yearly & $1954-1984$ & 1 \\
\hline (Lopez and Azzam, 2002) & PTA & Oligopoly & Yearly & $1972-1997$ & 25 \\
\hline (Lopez, He and Azzam, 2018) & SFE & Oligopoly & Yearly & $1990-2010$ & 23 \\
\hline $\begin{array}{l}\text { (Čechura, Kroupová and } \\
\text { Hockmann, 2015) }\end{array}$ & SFE & Oligopsony & Yearly & 2003-2012 & 94 \\
\hline $\begin{array}{l}\text { (Čechura, Kroupová and } \\
\text { Hockmann, 2015) }\end{array}$ & SFE & Oligopoly & Yearly & 2003-2012 & 70 \\
\hline (Mei and Sun, 2008) & PTA & Oligopsony & Yearly & $1955-2003$ & 1 \\
\hline (Mei and Sun, 2008) & PTA & Oligopoly & Yearly & $1955-2003$ & 1 \\
\hline (Merel, 2009) & GIM & Oligopoly & Quarterly & $1985-2005$ & 1 \\
\hline (Millán, 1999) & PTA & Oligopoly & Yearly & 1978-1992 & 14 \\
\hline
\end{tabular}




\begin{tabular}{|c|c|c|c|c|c|}
\hline (Murray, 1995) & PTA & Oligopsony & Yearly & $1958-1988$ & 1 \\
\hline (Murray, 1995) & PTA & Oligopsony & Yearly & 1958-1989 & 1 \\
\hline (Muth and Wohlgenant, 1999) & GIM & Oligopsony & Yearly & $1967-1993$ & 1 \\
\hline (O’Donnell et al., 2007) & GIM & Oligopsony & Yearly & $1989-2000$ & 28 \\
\hline (O’Donnell et al., 2007) & GIM & Oligopoly & Yearly & $1989-2000$ & 12 \\
\hline $\begin{array}{l}\text { (Panagiotou and Stavrakoudis, } \\
\text { 2017) }\end{array}$ & SFE & Oligopsony & Yearly & $1970-2009$ & 1 \\
\hline $\begin{array}{l}\text { (Panagiotou and Stavrakoudis, } \\
\text { 2018) }\end{array}$ & SFE & Oligopsony & Yearly & $1970-2009$ & 2 \\
\hline (Panagiotou, 2019) & SFE & Oligopsony & Yearly & $1970-2010$ & 3 \\
\hline (Perekhozhuk et al., 2013) & PTA & Oligopsony & Yearly & 1993-2006 & 2 \\
\hline (Perekhozhuk et al., 2015) & PTA & Oligopsony & Monthly & $1996-2003$ & 1 \\
\hline (Perekhozhuk et al., 2016) & GIM & Oligopsony & Monthly & $1996-2003$ & 1 \\
\hline (Perekhozhuk et al., 2016) & PTA & Oligopsony & Monthly & $1996-2003$ & 8 \\
\hline $\begin{array}{l}\text { (Lopez, Zheng and Azzam, } \\
\text { 2015) }\end{array}$ & SFE & Oligopoly & Yearly & $1979-2009$ & 36 \\
\hline $\begin{array}{l}\text { (Salhofer, Tribl and Sinabell, } \\
\text { 2012) }\end{array}$ & GIM & Oligopsony & Monthly & $1997-2008$ & 1 \\
\hline $\begin{array}{l}\text { (Salhofer, Tribl and Sinabell, } \\
\text { 2012) }\end{array}$ & GIM & Oligopoly & Monthly & $1997-2008$ & 1 \\
\hline (Bhuyan and Lopez, 1997) & PTA & Oligopoly & Yearly & $1972-1987$ & 37 \\
\hline (Scalco and Braga, 2014) & GIM & Oligopsony & Yearly & $1997-2011$ & 1 \\
\hline (Scalco, Lopez and He, 2017) & SFE & Oligopsony & Monthly & $2010-2015$ & 1 \\
\hline (Scalco, Lopez and He, 2017) & SFE & Oligopoly & Monthly & $2010-2015$ & 1 \\
\hline (Silva et al., 2019) & PTA & Oligopsony & Quarterly & 2016-2017 & 2 \\
\hline (Stalgienè and Jedik, 2015) & PTA & Oligopsony & Quarterly & 2004-2014 & 3 \\
\hline (Suzuki, Lenz and Forker, 1993) & GIM & Oligopoly & Yearly & 1979-1989 & 1 \\
\hline (Weerahewa, 2003) & GIM & Oligopsony & Yearly & $1970-2000$ & 3 \\
\hline (Weerahewa, 2003) & GIM & Oligopoly & Yearly & $1970-2000$ & 3 \\
\hline Total & & & & & 472 \\
\hline
\end{tabular}

Source: Articles cited, Note: the number of MPI depends on the number of supply chains analysed in the study

\section{Independent variables}

The first independent variable used in our analysis is "Observation number" variable calculated as the observation period multiplied with the data frequency (Table 1). We hypothesise that the higher number of observations used the lower average MP level is. For the analysis, we created "After 2005" dummy, to check if there is any difference in reported MP levels between older and newer papers. Also, we created Yearly dummy variables. This group of variables is aimed to capture variations of the observation frequency, which were used to estimate MPI. In the majority of the studies, data with yearly frequency was used for the MP estimation. The next variable is related to the approach used, namely: GIM, PTA and SFE (base factor). Another group of dummy variables are "Oligopsony" and "Oligopoly" which capture the direction of MP (input or output). The next group of the independent variables is based on the industry analysed. For our analysis, we grouped all observations in 8 main groups which have at least ten observations. As can be seen from Table 2, almost 20\% of all MPI observations are attributed to the "Dairy" sector, which includes milk, cheeses, butter, and other dairy products. "Beverages" dummy includes all the observations related to tea, coffee, wine, water, beer etc. Studies related to beef, hog or poultry, slaughtering are grouped in the "Meat" dummy. The Cereals category include observations which contain MPI of wheat, barley, oat and other grains. Most of the observations in this group can be attributed to the article by O'Donnell et al. [33]. The Oils group include observations of 
canola and other oils. "Tobacco", and "Fruits and Vegetables" variables are self-descriptive. Finally, Other industry consists of all other observations which cannot be included in any of the beforementioned groups; it also serves as a base group in the regression. Each of the beforementioned groups is used as a binary variable in further analysis.

The next variable is based on a geographical factor. Most of the studies were concluded using the data from the USA and other western countries. There is a relatively limited number of papers related to developing countries. Therefore, for our analysis, we decided to use regional dummy variables: USA, Europe and Other. First one includes all of the observations from the USA. The second variable contains countries of the European Economic Area. Furthermore, the "Other" dummy variable will consist of all other countries; also, it will serve as a base group to compare results with other variables.

Finally, we created the dummy variable "perishable" associated with the products with a short level of storability (eg. fluid milk, fresh meat etc.). The summary statistics of all variables can be seen in Table 2 .

Table 2. Descriptive Statistics

\begin{tabular}{lcccccc}
\hline \multicolumn{1}{c}{ Statistic } & Mean & St. Dev. & Min & Pctl(25) & Pctl(75) & Max \\
\hline MPI & 0.140 & 0.121 & 0.007 & 0.064 & 0.179 & 0.815 \\
Observations number & 19.874 & 25.987 & 4 & 9 & 20 & 348 \\
After 2005 & 0.706 & 0.456 & 0 & 0 & 1 & 1 \\
Yearly & 0.935 & 0.247 & 0 & 1 & 1 & 1 \\
Oligopsony & 0.349 & 0.477 & 0 & 0 & 1 & 1 \\
Oligopoly & 0.651 & 0.477 & 0 & 0 & 1 & 1 \\
Meat & 0.166 & 0.372 & 0 & 0 & 0 & 1 \\
Tobacco & 0.024 & 0.153 & 0 & 0 & 0 & 1 \\
Beverages & 0.081 & 0.273 & 0 & 0 & 0 & 1 \\
Dairy & 0.198 & 0.399 & 0 & 0 & 0 & 1 \\
Oils & 0.048 & 0.214 & 0 & 0 & 0 & 1 \\
Fruits and Vegetables & 0.122 & 0.328 & 0 & 0 & 0 & 1 \\
Cereals & 0.176 & 0.382 & 0 & 0 & 0 & 1 \\
Other industry & 0.185 & 0.389 & 0 & 0 & 0 & 1 \\
Europe & 0.460 & 0.499 & 0 & 0 & 1 & 1 \\
USA & 0.407 & 0.492 & 0 & 0 & 1 & 1 \\
Other countries & 0.133 & 0.340 & 0 & 0 & 0 & 1 \\
GIM & 0.118 & 0.323 & 0 & 0 & 0 & 1 \\
PTA & 0.320 & 0.467 & 0 & 0 & 1 & 1 \\
SFE & 0.562 & 0.497 & 0 & 0 & 1 & 1 \\
Perishable & 0.484 & 0.500 & 0 & 0 & 1 & 1 \\
\hline Articlescited & & & & & & 1 \\
\hline
\end{tabular}

Source: Articles cited

\section{Results and Discussion}

Based on the data introduced in the previous section, we developed four linear models which were estimated via OLS. In the first model (1) we included all variables related to the approach used and type of market power used in a study and the dummy "After 2005". Variables SFE and Oligopoly serve as a base group; therefore, the coefficients in each group can be compared with them. The second model (2) contains all the variables from the first and also variables related to data frequency of and geographical information of the MPI. Finally, the last model (3) includes all the data from previous models but also the information 
related to the industry in which MPI were observed. The last OLS model (4) also includes "perishability" dummy.

It should be noted that in the OLS models (1-4) from the initial dataset, we excluded 12 outliers which made OLS models less stable and might influence the reliability of the estimates. However, since those data points are not data entry errors, neither they are from a different population than most of our data. Therefore, we had no compelling reason to exclude these data points from our analysis entirely. Hence, this motivated us to make use of robust regression (5) [17] to be able to incorporate all the data into the model and to compare the results with the OLS estimates. The statistics of all five models can be seen in Table 3.

In all of the model, we used the log transformation of our dependent variable. It should be noted that even after the log transformation of the dependent variable, we could still reject the homoscedasticity hypothesis using Breusch Pagan Test. Thus, all the standard errors and marks of the statistical significance in Table 3 use these robust standard errors. The residualbased diagnostic tests proved the stability of all models.

Table 3. Regression Results

\begin{tabular}{|c|c|c|c|c|c|}
\hline & \multicolumn{5}{|c|}{ Market Power Index (log) } \\
\hline & \multicolumn{4}{|c|}{ OLS } & \multirow{2}{*}{$\begin{array}{c}\text { Robust } \\
\text { linear } \\
(5)\end{array}$} \\
\hline & (1) & (2) & (3) & (4) & \\
\hline \multirow[t]{2}{*}{ Intercept } & $-2.078 * * *$ & -0.272 & -0.546 & -0.419 & 0.186 \\
\hline & $(0.159)$ & $(0.642)$ & $(0.643)$ & $(0.642)$ & $(0.659)$ \\
\hline \multirow[t]{2}{*}{ PTA } & $0.350^{*}$ & 0.404 & $0.462 *$ & $0.465^{*}$ & $0.609 * *$ \\
\hline & $(0.152)$ & $(0.232)$ & $(0.235)$ & $(0.234)$ & $(0.214)$ \\
\hline \multirow[t]{2}{*}{ GIM } & $-0.606 * * *$ & -0.391 & -0.363 & -0.375 & -0.115 \\
\hline & $(0.163)$ & $(0.221)$ & $(0.222)$ & $(0.220)$ & $(0.214)$ \\
\hline \multirow[t]{2}{*}{ After 2005} & -0.305 & -0.130 & -0.067 & -0.080 & 0.039 \\
\hline & $(0.163)$ & $(0.237)$ & $(0.245)$ & $(0.244)$ & $(0.227)$ \\
\hline \multirow[t]{2}{*}{ Oligopsony } & -0.023 & 0.008 & -0.008 & -0.004 & -0.107 \\
\hline & $(0.072)$ & $(0.075)$ & $(0.074)$ & $(0.073)$ & $(0.058)$ \\
\hline \multirow[t]{2}{*}{ Obs. Num. (log) } & & $-0.546 * * *$ & $-0.539 * * *$ & $-0.540 * * *$ & $-0.682 * * *$ \\
\hline & & $(0.100)$ & $(0.099)$ & $(0.099)$ & $(0.129)$ \\
\hline \multirow[t]{2}{*}{ Yearly } & & $-0.788 * *$ & $-0.760 * *$ & $-0.783 * *$ & $-0.945^{* *}$ \\
\hline & & $(0.282)$ & $(0.279)$ & $(0.279)$ & (0.303) \\
\hline \multirow[t]{2}{*}{ USA } & & $0.548 * *$ & $0.607 * *$ & $0.542 * *$ & $0.499 * *$ \\
\hline & & $(0.182)$ & $(0.187)$ & $(0.188)$ & $(0.188)$ \\
\hline \multirow[t]{2}{*}{ Europe } & & 0.014 & 0.007 & 0.004 & -0.081 \\
\hline & & $(0.157)$ & $(0.155)$ & $(0.154)$ & $(0.135)$ \\
\hline \multirow[t]{2}{*}{ Meat } & & & 0.191 & $0.565 * * *$ & $0.600 * *$ \\
\hline & & & $(0.127)$ & $(0.169)$ & $(0.192)$ \\
\hline \multirow[t]{2}{*}{ Tobacco } & & & $0.443^{*}$ & 0.397 & 0.285 \\
\hline & & & $(0.208)$ & $(0.207)$ & $(0.195)$ \\
\hline \multirow[t]{2}{*}{ Beverages } & & & 0.222 & 0.170 & 0.123 \\
\hline & & & $(0.164)$ & $(0.166)$ & $(0.152)$ \\
\hline \multirow[t]{2}{*}{ Dairy } & & & 0.145 & $0.473 * *$ & $0.485 * *$ \\
\hline & & & $(0.133)$ & $(0.163)$ & $(0.188)$ \\
\hline \multirow[t]{2}{*}{ Oils } & & & -0.100 & -0.147 & -0.341 \\
\hline & & & $(0.171)$ & $(0.175)$ & $(0.188)$ \\
\hline
\end{tabular}




\begin{tabular}{|c|c|c|c|c|c|}
\hline \multirow[t]{2}{*}{ Fruits } & & & 0.167 & $0.529 * *$ & $0.594 * *$ \\
\hline & & & $(0.142)$ & $(0.173)$ & $(0.189)$ \\
\hline \multirow[t]{2}{*}{ Cereals } & & & 0.247 & 0.170 & 0.005 \\
\hline & & & $(0.148)$ & $(0.156)$ & $(0.132)$ \\
\hline \multirow[t]{2}{*}{ Perishable } & & & & $-0.450 * *$ & $-0.583 * *$ \\
\hline & & & & $(0.168)$ & $(0.185)$ \\
\hline Observations & 459 & 459 & 459 & 459 & 472 \\
\hline R-squared & 0.231 & 0.295 & 0.311 & 0.321 & \\
\hline Residual standard error & 0.700 & 0.673 & 0.671 & 0.667 & 0.548 \\
\hline F statistic & $34.134 * * *$ & $23.535 * * *$ & $13.346^{* * *}$ & $13.072 * * *$ & \\
\hline
\end{tabular}

First and foremost, let us review methodology related variables, which are PTA and GIM. It should be noted that there is indeed a systematic difference between the approach used and an MP estimate. Most of the models suggest that PTA estimates, provide $40 \%$ higher MP estimates than GIM and SFE (which is a base group). We perceive the last two models as more reliable and descriptive since they take into account more nuances. Therefore, according to our analysis, we can conclude that PTA studies tend to report a higher level of MP than other two methods. At the same time, there is no statistically significant difference between GIM and SFE. From our study, we cannot conclude which estimates are more "correct" and reliable. We can only state that there is a systematic difference in the estimates.

Another notable finding is that there is a high and consistent correlation between a number of observations used for MP estimation with the reported results. According to our analysis, we can say that increase in the number of observations by $1 \%$ on average decrease MPI on approximately $0.54 \%$. This observation might be explained that articles with a small sample size are more likely to report an extreme level of MP and vice versa. At the same time, studies with Yearly data frequency tend to report around 75\% lower MPI estimates than studies with more frequent data. In other words, a long observation period used in a study, on average, provide significantly lower estimates, which may occur due to the regression toward the mean effect.

It should also be noted that there is a dramatical difference between the average level of MP in the USA and other countries. According to our analysis articles based on US data, on average, report $60 \%$ higher MP level as in other countries. At the same time, there is no evidence that there is a statistically significant difference between Europe and other countries.

At the same time, we can reject the hypothesis of difference in MP estimate in older and newer articles, the variable After 2005 does not differ from zero in any of the models. There is also no statistically significant difference between Oligopoly and Oligopsony MP estimates.

Among all of the industry variables, without including perishable dummy, we can say that only MPIs related to Tobacco systematically higher than industry groups. However, after the addition variable, which captures the perishability of a product, the results change significantly. With controlling for perishability, we can say that on average, meat, milk and horticulture industries have around 50\% higher market power that other agricultural supply chains. Another interesting finding is that perishable goods turn out to be quite strongly negatively correlated with the level of market power. This result is a little unexpected since the traditional microeconomic theory suggests the opposite correlation direction. Understanding the reason why happens so is yet to be understood and requires further investigation. 
The results of a robust regression are in line with the other OLS models, even though some coefficients vary slightly, both the direction and magnitude of correlations are virtually the same. The $r$ square statistic is not reported for the fifth model since it is not appropriate directly compare this statistic in robust regression with the one in OLS. However, smaller residual standard error suggests a slightly better fit of the robust regression.

Finally, it should be mentioned that taking into account the considerable data limitations, the results of this analysis should be perceived with high caution. This paper is just a first attempt to understand the underlying mechanism of market power formation, and by all means, it requires a further extension. In future, this research can be extended by including proxies of organisational structures, barriers to entry, supply chain structure and other variables to examine the relationship between market structure and the level of market power.

\section{Conclusion}

This paper aims to investigate the systematic differences in market power estimates between agriculture supply chains and to assess the determinants of market power estimates. We employed a meta-analysis approach and using linear models and robust linear regression we estimated the impact of the estimation method and additional variables on the market power index obtained in up to date published studies. According to our analysis, we can conclude that PTA studies tend to report a higher level of MP than other two methods. At the same time, there is no statistically significant difference between GIM and SFE. We can also conclude that increase in the number of observations by $1 \%$ on average decrease MPI on approximately $0.54 \%$. Usage of Yearly data frequency in estimation is associated with a $75 \%$ decrease in the derived MPI estimate, compared to monthly or weekly data frequency. Having all other variables fixed, articles based on US data report $60 \%$ higher MP level as in other countries; however, there is no evidence of the statistically significant difference between Europe and other countries. The level of market power, on average, is 50\% higher in meat, dairy and horticulture industries. The final finding is that perishable products have a lower average level of market power.

We gratefully acknowledge the financial support received from the Slovak Research and Development Agency under the contract No. APVV-18-0512 (Slovak Republic) and GAČR project 19-18080S (Czechia).

\section{References}

1. Ahn, B. I., Lee, H. (2010). An equilibrium displacement approach to oligopoly market analysis: an application to trade in the Korean infant formula market. Agricultural Economics, 41(2), 101-109.

2. Anders, S. M. (2008). Imperfect Competition in German Food Retailing: Evidence from State Level Data. Atlantic Economic Journal, 36(4), 441-454.

3. Appelbaum, E. (1982). The estimation of the degree of oligopoly power. Journal of Econometrics, 19(2-3), 287-299.

4. Azzam, A. M., Pagoulatos, E. (1990). Testing Oligopolistic and Oligopsonistic Behaviour: An Application to the US Meat-Packing Industry. Journal of Agricultural Economics, 41(3), 362-370.

5. Bakucs, L. Z., Ferto, I., Hockmann, H., Perekhozhuk, O. (2009) Market power on the edge? An analysis of the German and Hungarian hog markets, German Journal of Agricultural Economics, 58(8), 337-345. 
6. Bergman, M. A., Brannlund, R. (1995). Measuring Oligopsony Power: An Application to the Swedish Pulp and Paper Industry. Review of Industrial Organization, 10(3), 307321.

7. Bettendorf, L., Verboven, F. (2000). Incomplete transmission of coffee bean prices: evidence from The Netherlands. European Review of Agricultural Economics, 27(1), 116.

8. Bhuyan, S. (2014). Visiting an old battleground in empirical industrial organisation: SCP versus NEIO. Applied Economics Letters, 21(11), 751-754.

9. Bhuyan, S., Lopez, A. (1997). Oligopoly Power in the Food and Tobacco Industries, American Journal of Agricultural Economics, 79(3), 1035-1043.

10. Bhuyan, S., Lopez, A. (1998). Oligopoly Power and Allocative Efficiency in US Food and Tobacco Industries. Journal of Agricultural Economics, 49(3), 434-442.

11. Čechura, L., Kroupová, Z., Hockmann, H. (2015). Market Power in the European Dairy Industry. Agris on-line Papers in Economics and Informatics, 7(4), 39-47.

12. Chen, Y., Yu, X. (2018). Does the centralised slaughtering policy create market power for pork industry in China? China Economic Review, 50, pp. 59-71.

13. Chidmi, B., Lopez, R. A., Cotterill, R. W. (2005). Retail oligopoly power, dairy compact, and Boston milk prices. Agribusiness, 21(4), 477-491.

14. Chirinko, R. S., Fazzari, S. M. (1994). Economic Fluctuations, Market Power, and Returns to Scale: Evidence from Firm-Level Data. Journal of Applied Econometrics, 9(1), 47-69.

15. European Commission (2009). Analysis of price transmission along the food supply chain in the EU, p. 69.

16. Genesove, D., Mullin, W. P. (1998). Testing Static Oligopoly Models: Conduct and Cost in the Sugar Industry, 1890-1914. The RAND Journal of Economics, 29(2), 355-377.

17. Hampel, F.R., Ronchetti, E.M., Rousseeuw, P.J., Stahel, W.A. (2005). Linear Models: Robust Estimation. Robust Statistics: The Approach Based on Influence Functions. John Wiley \& Sons, Ltd, 307-341.

18. Hockmann, H., Vöneki, É. (2009). Collusion in the Hungarian Market for Raw Milk. Outlook on Agriculture, 38(1), 39-45.

19. Hovhannisyan, V., Gould, B. W. (2012). A Structural Model of the Analysis of Retail Market Power: The Case of Fluid Milk. American Journal of Agricultural Economics, 94(1), 67-79.

20. Ji, I., Chung, C. (2016). Assessment of Market Power and Cost Efficiency Effects in the U.S. Beef Packing Industry. Journal of Rural Development/Nongchon-Gyeongje.

21. Kumbhakar, S. C., Baardsen, S. and Lien, G. (2012) 'A New Method for Estimating Market Power with an Application to Norwegian Sawmilling', Review of Industrial Organization, 40(2), pp. 109-129. doi: 10.1007/s11151-012-9339-7.

22. Lopez, A. (1984). Measuring Oligopoly Power and Production Responses of the Canadian Food Processing Industry Journal of Agricultural Economics, 35(2), 219-230.

23. Lopez, A., Azzam, M. (2002). Market Power and/or Efficiency: A Structural Approach. Review of Industrial Organization, 20(2), 115-126.

24. Lopez, A., He, X., Azzam, A. (2018). Stochastic Frontier Estimation of Market Power in the Food Industries. Journal of Agricultural Economics, 69(1), 3-17.

25. Lopez, A., You, Z. (1993). Determinants of oligopsony power: The Haitian coffee case. Journal of Development Economics, 41(2), 275-284. 
26. Lopez, A., Zheng, H., Azzam, A. (2015). Oligopoly Power in the Food Industries Revisited: A Stochastic Frontier Approach, AgEcon Search. Retrieved from: https://ageconsearch.umn.edu/record/205113/

27. Mei, B., Sun, C. (2008). Assessing Time-Varying Oligopoly and Oligopsony Power in the U.S. Paper Industry. Journal of Agricultural and Applied Economics, 40(3), 927939.

28. Mello, M. D., Brandao, A. (1999). Measuring the Market Power of the Portuguese Milk Industry. International Journal of the Economics of Business, 6(2), 209-222.

29. Merel, P. R. (2009). Measuring market power in the French Comte cheese market. European Review of Agricultural Economics, 36(1), 31-51.

30. Millán, J. A. (1999). Short-run equilibrium and market power in the Spanish food, drink and tobacco industries. European Review of Agricultural Economics, 26(2), 229-243.

31. Murray, B. C. (1995). Measuring Oligopsony Power with Shadow Prices: U.S. Markets for Pulpwood and Sawlogs. The Review of Economics and Statistics, 77(3), 486-498.

32. Muth, M. K. and Wohlgenant, M. K. (1999). Measuring the Degree of Oligopsony Power in the Beef Packing Industry in the Absence of Marketing Input Quantity Data. Journal of Agricultural and Resource Economics, 24(2), 299-312.

33. O’Donnell, C. J., Griffith, G. R., Nightingale, J. J., Piggott, R. R. (2007). Testing for market power in the Australian grains and oilseeds industries. Agribusiness, 23(3), 349376.

34. Panagiotou, D. (2019). Market Power Effects of the Livestock Mandatory Reporting Act in the U.S. Meat Industry: a Stochastic Frontier Approach Under Uncertainty. Journal of Industry, Competition and Trade, 19(1), 103-122.

35. Panagiotou, D., Stavrakoudis, A. (2017). A Stochastic Production Frontier Estimator of the Degree of Oligopsony Power in the U.S. Cattle Industry. Journal of Industry, Competition and Trade, 17(1), 121-133.

36. Panagiotou, D., Stavrakoudis, A. (2018). A stochastic frontier estimator of the aggregate degree of market power exerted by the US meat packing industry. Economia e Politica Industriale, 45(3), 387-401.

37. Perekhozhuk, O., Hockmann, H., Ferto, I., Bakucs, Z. (2013). Identification of Market Power in the Hungarian Dairy Industry: A Plant-Level Analysis. Journal of Agricultural \& Food Industrial Organization, 11(1), 1-13.

38. Perekhozhuk, O., Glauben, T., Teuber, R., Grings, M (2015). Regional-Level Analysis of Oligopsony Power in the Ukrainian Dairy Industry. Canadian Journal of Agricultural Economics/Revue canadienne d'agroeconomie, 63(1), 43-76.

39. Perekhozhuk, O., Glauben, T., Grings, M., Teuber, R. (2016). Approaches and Methods for the Econometric Analysis of Market Power: A Survey and Empirical Comparison: Econometric Analysis of Market Power. Journal of Economic Surveys, 31(1), 303-325.

40. Salhofer, K., Tribl, C., Sinabell, F. (2012). Market power in Austrian food retailing: the case of milk products. Empirica, 39(1), 109-122.

41. Scalco, R., Braga, J. (2014). Measuring the Degree of Oligopsony Power in the Brazilian Raw Milk Market. International Food and Agribusiness Management Review, 17(2), 120.

42. Scalco, R., Lopez, A., He, X. (2017). Buyer and/or seller power? An application to the Brazilian milk market. Applied Economics Letters, 24(16), 1173-1176.

43. Silva, B. K. et al. (2019) 'Assessing market power in the U.S. pulp and paper industry', Forest Policy and Economics, 102, pp. 138-150. doi: 10.1016/j.forpol.2019.03.009. 
44. Stalgienè, A., Jedik, A. (2015). Oligopsony power in agricultural market: the case of the Lithuanian raw milk market. Management Theory and Studies for Rural Business and Infrastructure Development, 37(1), 114-121.

45. Stiegert, K. W., Wang, S.-S., Rogers, R. T. (2009). Structural change and market power in the U.S. food manufacturing sector. Agribusiness, 25(2), 164-180.

46. Suzuki, N., Lenz, J. E., Forker, O. D. (1993). A Conjectural Variations Model of Reduced Japanese Milk Price Supports. American Journal of Agricultural Economics, 75(1), 210-218.

47. Swinnen, J. F. M., Vandeplas, A. (2010). Market power and rents in global supply chains. Agricultural Economics, 41, 109-120.

48. Weerahewa, J. (2003). Estimating Market Power of Tea Processing Sector. Sri Lankan Journal of Agricultural Economics, 5, 69-82. 